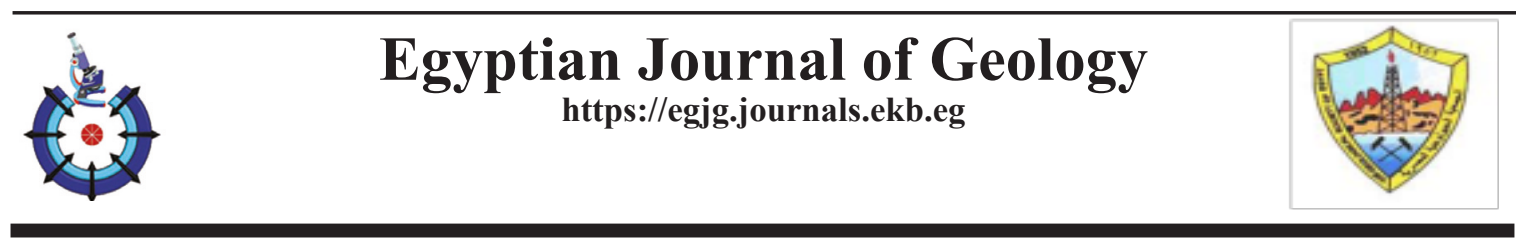

\title{
Hydrogeological Characteristics of the Quaternary Aquifer in Beni Suef Area, Egypt
}

\author{
M. Albadr*, A. M. El-Kammar**, M. M. Yehia***, M. M. El Kammar**, Hend S. Abu \\ Salem** \\ *El-Minya Company for Drinking Water and Wastewater, **Geology Department, Faculty \\ of Science, Cairo University, ***Central Laboratory for Environmental Quality Monitoring, \\ National Water Research Centre, Kanater El-Khairia, Egypt
}

\begin{abstract}
CROUNDWATER exploitation in arid and semi-arid areas leads to several hazards such as water level decline, aquifer salinization, water quality deterioration, and waterlogging. The study area is represented by El Fashn District, Beni Suef Governorate, Egypt. The objective of this study is the investigation of the hydrogeological properties of the Quaternary aquifer in Beni Suef area based on the data obtained from the technical reports of REGWA for the years 1996, 2003, 2014 and 2017. In addition, the waterlogging phenomena is considered to allocate areas that adversely affected by soil salinization. Two main aquifers characterize the study area: The Middle Pleistocene and the Early Pleistocene aquifers. The Holocene sediments act as aquitard of the Middle Pleistocene whereas the Early Pleistocene is lacking the Holocene aquitard. Accordingly, the study area is classified based on aquitard thickness into four zones. The Middle Pleistocene aquifer has a maximum thickness of $200 \mathrm{~m}$ in the middle parts of the Nile valley near Beni-Suef and diminishes in both the eastern and western directions, whereas the Early Pleistocene aquifer thickness ranges from $81 \mathrm{~m}$ to $85 \mathrm{~m}$ with a saturated thickness of 64 to $82 \mathrm{~m}$ in the study area. The transmissivity of the aquifer is obtained using Cooper-Jacob method. It varies from about 769 to $4796 \mathrm{~m}^{2} / \mathrm{d}$ for the Early Pleistocene aquifer, and from 656 to $28602 \mathrm{~m}^{2} / \mathrm{d}$ for the Middle Pleistocene aquifer. Accordingly, the Quaternary aquifer in the study area is characterized by high potentiality according to Gheorghe classification.

Comparison between the water level maps indicate that there is no change in the groundwater flow direction (from west to northeast direction with the general slope). Although, the slight rise of the groundwater level is apparent in the west part of the study area which may be related to flooding irrigation technique. The waterlogging phenomena is studied in the study area where bad effects on soil are recorded. The investigated area was classified into three areas based on the Indian Ministry of Water Resources classification for waterlogging, which are waterlogged, potential and safe areas.
\end{abstract}

Keywords: Hydrogeology, Quaternary aquifer, pumping test, waterlogging, Beni Suef, Egypt.

\section{Introduction}

Groundwater represents a significant part of the total water resources used for drinking and irrigation purposes, especially in arid and semiarid areas) Tsujimura, et al., (2007), Keesari, et al., (2014), In the past few decades, an increase of groundwater usage has been remarked due to drought, growth of the world economy as well as population) Llamas and Martínez-Santos (2005).Egypt represents one of the countries that suffer from water shortage due to high population growth and possible decrease of the River Nile share due to the construction of the Grand Ethiopian Renaissance Dam (GERD). As a result of increasing demands and water shortage, the groundwater is heavily exploited.

Correponding author: Albadr, Mohammed Albadr, Email: mohammedalbadr20@gmail.com

Received: 01/10/2021; Accepted: 07/11/2021

DOI: 10.21608/egjg.2021.93986.1005

(C)2021 National Information and Documentation Center (NIDOC) 
Good investigation of the aquifer characteristics is important in water management plans. In addition, the possible hazards that may affect the groundwater quality or quantity should be determined. These hazards include, water level decline, aquifer salinization, water quality deterioration, and waterlogging.

The study area is represented by El Fashn District, Beni Suef Governorate, Egypt, that lies on the west flood plain of the River Nile valley where the main developmental activities is agriculture. The essential water resources used for irrigation and domestic purposes are the Nile River, the Ibrahimiya canal, Bahr Youssef canal, irrigation canals and drains in addition to groundwater. Groundwater is only used in areas distant from the surface water or in seasons of increased demand .Approximately $92 \%$, of the Nile River water share for Beni Suef governorate is used for irrigation $5 \%$, for drinking and 3\% for industry (EEAA, 2003), The irrigation is commonly achieved through flood techniques while dripping irrigation is used in a limited extent.

The study area is characterized by intensive agricultural activities and is undergoing a notable water shortage especially in the western parts; the west of Bahr Youssef canal, where the groundwater is heavily consumed. Moreover, waterlogging is dominant in some parts of the study area, resulting in soil amendment and may be abandonment of land. Therefore, the main objective of this study is investigation of the hydrogeological properties of the Quaternary aquifer in Beni Suef area based on the data from the technical reports of REGWA for the years 2003, 1996 2014, and 2017. In addition, the waterlogging phenomena is considered to allocate the areas that adversely affected by soil salinization. Generally, the agricultural productivity of about third of the world's irrigated lands decreased as a result of poor irrigation techniques that drive salinization and waterlogging (Fernández Cirelli, et al ., 2009). Additionally ,in arid and semi-arid regions around the world, the land is affected by waterlogging problem due to canal irrigation that accompanied by poor drainage system (Sarvade, et al., 2017).

\section{Study Area}

The investigated area is located in the western part of the Nile valley, El-Fashn District in the southwest of Beni Suef Governorate, Egypt. It is located between latitudes $28^{\circ} 43^{\prime}$ and $29^{\circ} 01^{\prime} \mathrm{N}$ and longitudes $30^{\circ} 43^{\prime}$ and $31^{\circ} 02^{\prime} \mathrm{E}$ (Fig. 1). It is also bounded from the east by the Nile River, from the west by the Western Desert ,from the north by El-Faiyum Governorate, and from the south by El-Minya Governorate, with an area of about890 $\mathrm{km} 2$. It is characterized by four distinctive surface water bodies: the Nile River and the Ibrahimiya canal in east, El-Moheet Drain in the middle, and Bahr Youssef canal in the west. These water bodies run in the old cultivated are to the east of the reclaimed desert area in the west of Bahr Youssef canal (Fig. 1).

Beni Suef area has an arid desert climate typical of Group BWh in the Köppen climate classification (Köppen, 1918; Peel, et al., 2007). It is characterized by little precipitation, hot summer and warm winter with cool nights. The monthly average minima and maxima of air temperatures are highest in July $\left(38.91{ }^{\circ} \mathrm{C}\right.$ and $\left.21.45^{\circ} \mathrm{C}\right)$ and lowest in January $\left(19.16^{\circ} \mathrm{C}\right.$ and $5.18{ }^{\circ}$ C) (C.F.S.R.,2011-2013). The study area is characterized by low precipitation rate with a maximum precipitation of $0.31 \mathrm{~mm}$ in January and a minimum value of $0.01 \mathrm{~mm}$ in February, March, and October. The study area shows a wide range of relative humidity percent values in the period from 2011 to 2013 where the highest record is $65 \%$ in December and the lowest record is $29 \%$ in May. Wind speed ranges from $2.89 \mathrm{~m} / \mathrm{s}$ in June to $1.74 \mathrm{~m} / \mathrm{s}$ in January in the period from 2011 to 2013.

Based on geomorphic features, the study area is classified regionally into four units which are: Young Alluvial plains, Fanglomerates, Old Alluvial plains, and Calcareous plateau (Fig. 2).

\section{Geological Setting}

The Quaternary deposits cover the study area and lie unconformably over the Pliocene and older sediments (Attia, 1954; Hassan, et al., 1978; Said, 1981; Said, 1990) (Fig. 3). Several structural lineaments control the structural setting of the study area: the Red Sea and the Gulf of Suez (NW- SE) and the Syrian Arc system (NE- SW) (El Abd, 2015). The stratigraphic section of the study area is discussed from oldest to youngest as follows:

The Pleistocene Deposits rest unconformably on the Eocene deposits in the surface exposures while they rest conformably on the Pliocene deposits in the subsurface. According to (Said, 1990), the Pleistocene deposits are divided into three units on the basis of their texture, structural and mineral composition: 


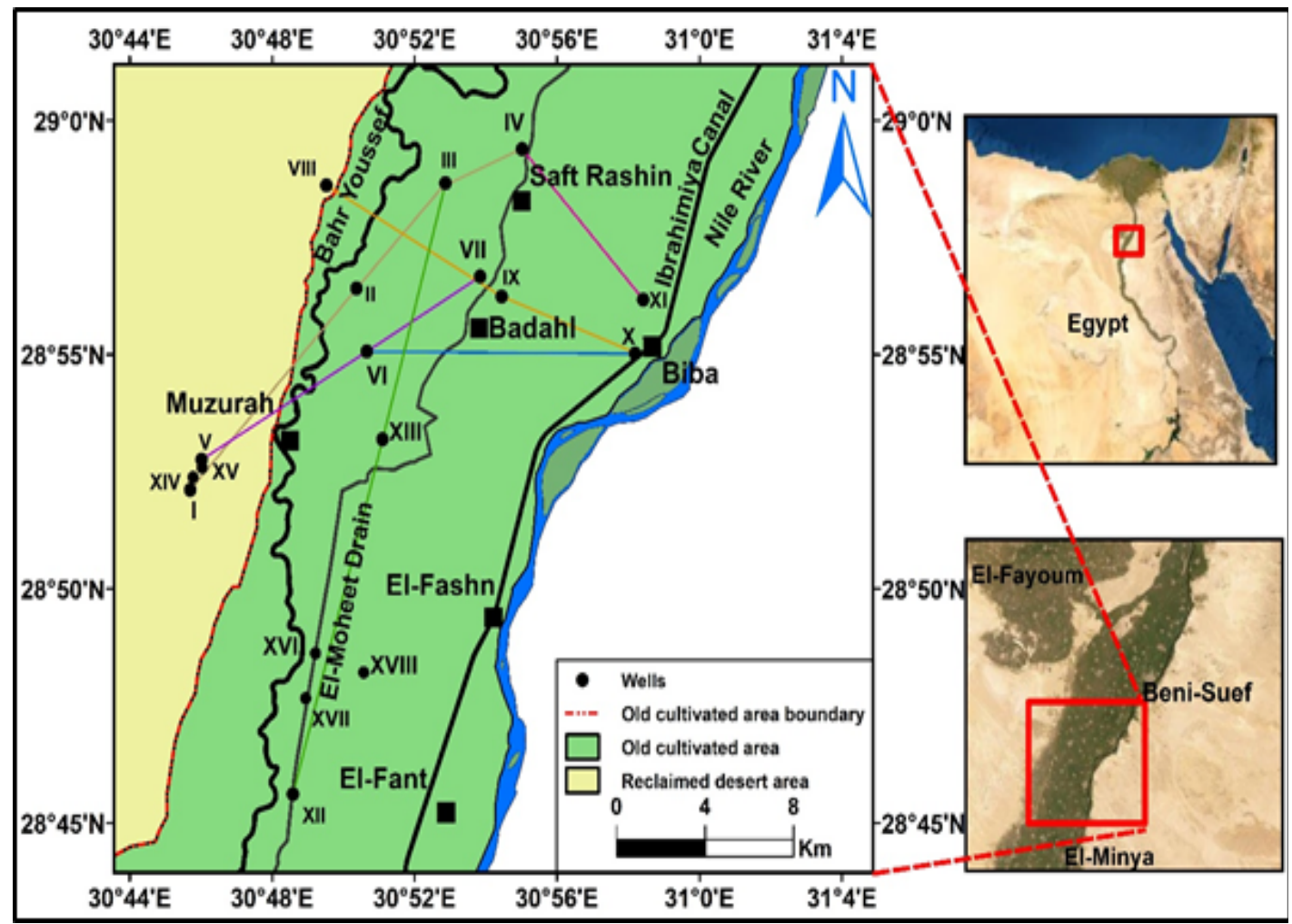

Fig. 1. Location map of Beni Suef in El Fashn District, Egypt.

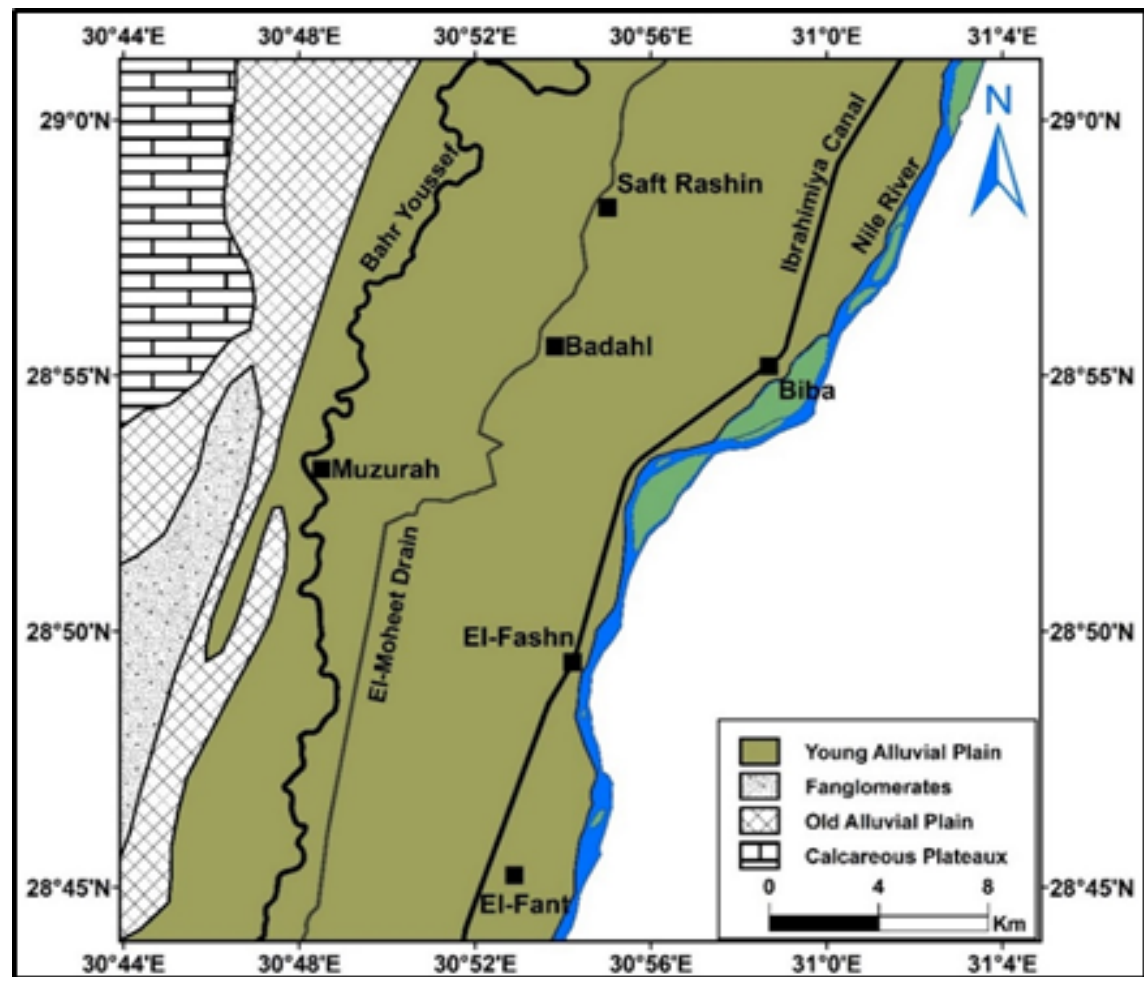

Fig. 2. Geomorphic map of Beni Suef area (modified after Said, 1981). 
The Early Pleistocene (the Protonile deposits, Q1) is represented by Idfu Formation that is made up of gravels and sands of quartz and quartzite compositions and are embedded in a red-brown matrix (Said, 1975, 1981), its thickness may exceed $20 \mathrm{~m}$ (Said, 1975, 1981). These sediments were derived from deeply leached terrain and from local sources and stretch along the west bank of the Nile River (Said, 1990).

Plio-Pleistocene (Paleo-Protonile Interval) is characterized by two different formations belonging to the Early Pleistocene. The older one is known as Armant Formation which is made up of alternating beds of locally derived gravels that are cemented by tufaceous materials, and fine grained clastic rocks that are calcareous sandy, shaly or phosphatic depending on the nearby source rock (Said, 1975, 1981). The Armant Formation is overlain by the Issawia Formation which is characterized by the deposition of bedded and/or massive tufas associated with thick talus breccias that deposited during high seismicity episode (Said, 1990). The Armant and Issawia formations are of Early Pleistocene age (Said, 1981; Said, 1990), where the Armant Formation is believed to be deposited during the Early Pleistocene pluvial period. This aquifer is unconfined to semi-confined due to the lack of thick clay bed. The groundwater level is higher than the Nile water level so the river shows effluent conditions (El Sayed, 1993).

The Middle Pleistocene (The Prenile deposits, Q2) is represented by Qena Formation that is made up of massive cross-bedded fluvial sands interbedded with dune sand, and is terminated by deposition of the Abbassia I and Abbassia II, which are known as the Abbassia Formation. The Abbassia Formation is composed of massive loosely consolidated gravels of polygenetic origin which are derived from uncovered basement of the Eastern Desert after the severance of connection between the Egyptian Nile with the Ethiopian Highlands (Said, 1981; Said, 1990). The Abbassia Formation rests unconformably on the Qena Formation. The time of deposition of the Abbassia Formation is interrupted by deposition of silts of the Dandara Formation ( $=\alpha$ Neonile silts) which is in distinguished from those of the modern Nile (Said, 1990). The Prenile sediments represent the main aquifer of the study area, where they are found in the surface exposure in the western part of the study area and are found in subsurface of the central part of the study area.

The Late Pleistocene (The Neonile deposits, Q3) are represented by the Korosko Formation

Egypt. J. Geo. Vol. 65 (2021) which includes the deposits of two major Pluvials: the Saharan I and Saharan II, with two or more silts occurred in the midst of recessional deposits (Said, 1990). Butzer and Hansen (1968) described the Korosko Formation as sandy-marly unit forming what these authors termed the Basal Sands and Marls of Kom Ombo Nilotic succession followed by the deposition of Younger Neonile deposits ( $\beta$, $\gamma, \delta$ deposits) that consist of massive structured silts with interfingering dune sand (Said, 1990).

The Holocene Deposits are formed of unconsolidated sediments that fill the study area and comprise the Nile silts, the sand dunes, and the fanglomerates.

The Nile Silts have a wide distribution along the investigated area, with average thickness of about $12 \mathrm{~m}$ (Attia, 1954). The Nile Silt deposits rest unconformably on the Middle Pleistocene deposits (Prenile deposits). According to Attia (1954), these deposits are represented by clay, sandy clay, clayey sand and fine to medium sand. The Nile silt deposits were considered by Said (1981); Said (1990) as the youngest Neonile deposits and was designated as the $\beta, \gamma, \delta$ Nile Silts. The Sand Dunes cover the western part of the study area as well as parts of the cultivated land. These deposits represent Late Pleistocene to Holocene age. The Fanglomerates formed from several wadis, where they fan out and deposit their load before reaching the Nile River. They are dominated in the west of the study area (west of El-Fashn, the western bank of the Nile Valley), and exhibiting elongate strips or triangular shapes. According to Hassan et al. (1978), these sediments are composed mainly of conglomerate and loose sand and attain a thickness of few centimetres at the edges to a few meters near their centres. The length of the fans ranges from $3.5 \mathrm{~km}$ to $15 \mathrm{~km}$, while the width varies from $4.5 \mathrm{~km}$ to $9.5 \mathrm{~km}$.

\section{Methodology}

The hydrogeologic information obtained from the technical reports of REGWA in 1996, 2003, 2014, 2017 were used to study the hydrogeological characteristics of the Pleistocene aquifer in the study area. Other resources include the geological map of Egypt (NH $36 \mathrm{SW}$ Beni Suef, scale 1:500000) (Conoco Coral, et al., 1987) and lithostratigraphic column of surface sediments based on measured sections along the Nile Valley banks (Said, 1990). The transmissivity was calculated from the analyses of pumping test data of 16 selected wells using Cooper- Jacob method Cooper Jr and Jacob,(1946). 


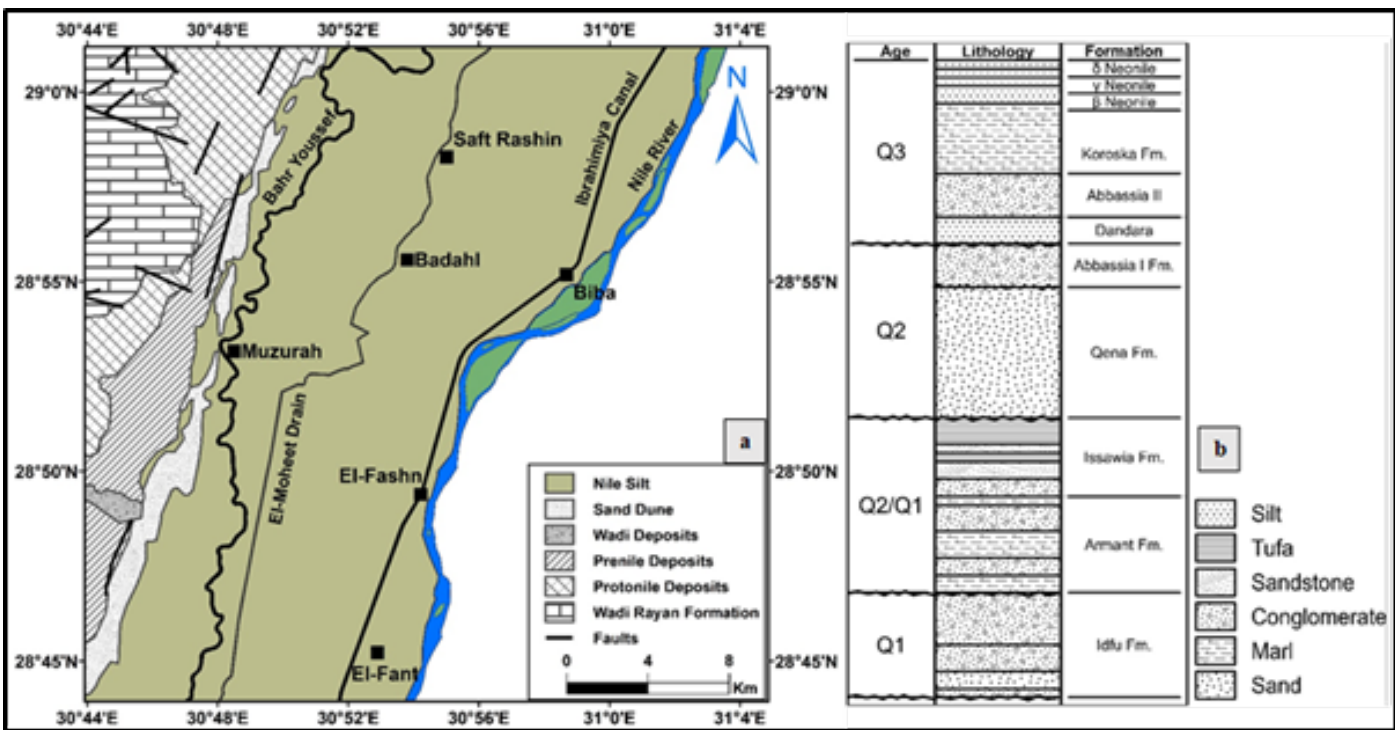

Fig.3 a Geological map of the study area modified after, Conoco Coral, et al, (1987),.b (Lithostratigraphic column of surface sediments based on measured sections along the Nile Valley banks modified after) Said. (1990), The lithostratigraphic composite section is exaggerated two and half times the subsurface section.

The desktop work of the present study includes the following software: STARTER v3.2.637 was used for drawing the lithostratigraphic sections. Google Earth Pro v7.3.2.5776 was used to obtain the satellite image. Grapher v12.3.734 and v14.2.371 were used for drawing charts of pumping tests. RockWorks 16 software was used for designing lithostratigraphic cross sections. Global Mapper v17.1.0 and ArcGIS 10.3 and 10.5 were used for designing different maps (geological, hydrogeological and others), AutoCAD vm.49.0.0 is used for enhancing cross sections.

\section{Results and Discussion}

\section{Hydrogeological Characteristics of the Quaternary aquifer}

Aquitard Distribution

The Holocene sediments constitute the principal aquitard in the study area which are mainly composed of clay ranging in thickness from $4 \mathrm{~m}$ in the west to more than $15 \mathrm{~m}$ in the northeast and southern parts of the study area (Fig. 4) The variation in the aquitard thickness leads to varying hydraulic connections between surface and groundwater.

The study area is classified according to the aquitard thickness into four zones (Fig. 4a). In the southern and northeast parts, a maximum thickness of aquitard was reported (more than 15 $\mathrm{m}$ ) whereas the western parts show a minimum thickness (less than $5 \mathrm{~m}$ ). Accordingly, the aquitard thickness increases gradually from the west to the northeast and the south parts (Fig. 4b, Appendix 1).

The Middle Pleistocene aquifer is overlain by the Holocene deposits that dominate the central and eastern parts and act as aquitard, so this aquifer undergoes semi-confined to confined conditions. However in the west, the top of the Early Pleistocene sediments is lacking the Holocene aquitard and an unconfined conditions prevail (El Sayed, 1993).

The Middle Pleistocene aquifer has a maximum thickness of about $200 \mathrm{~m}$ in the middle parts of the Nile Valley near Beni Suef and diminishes in both eastern and western directions from north to south El Sayed, (1993). Additionally, the thickness of the Early Pleistocene aquifer ranges from 81 $\mathrm{m}$ to $85 \mathrm{~m}$, while its saturated thickness ranges from $64 \mathrm{~m}$ to $82 \mathrm{~m}$, which is represented in well I. The Early Pleistocene aquifer is characterized by an average saturated thickness of about $70 \mathrm{mEl}$ Sayed, (1993).

The aquifer and aquitard distribution of the studied wells is further investigated through the construction of several hydrogeologic cross sections. Six hydrogeological cross sections were 


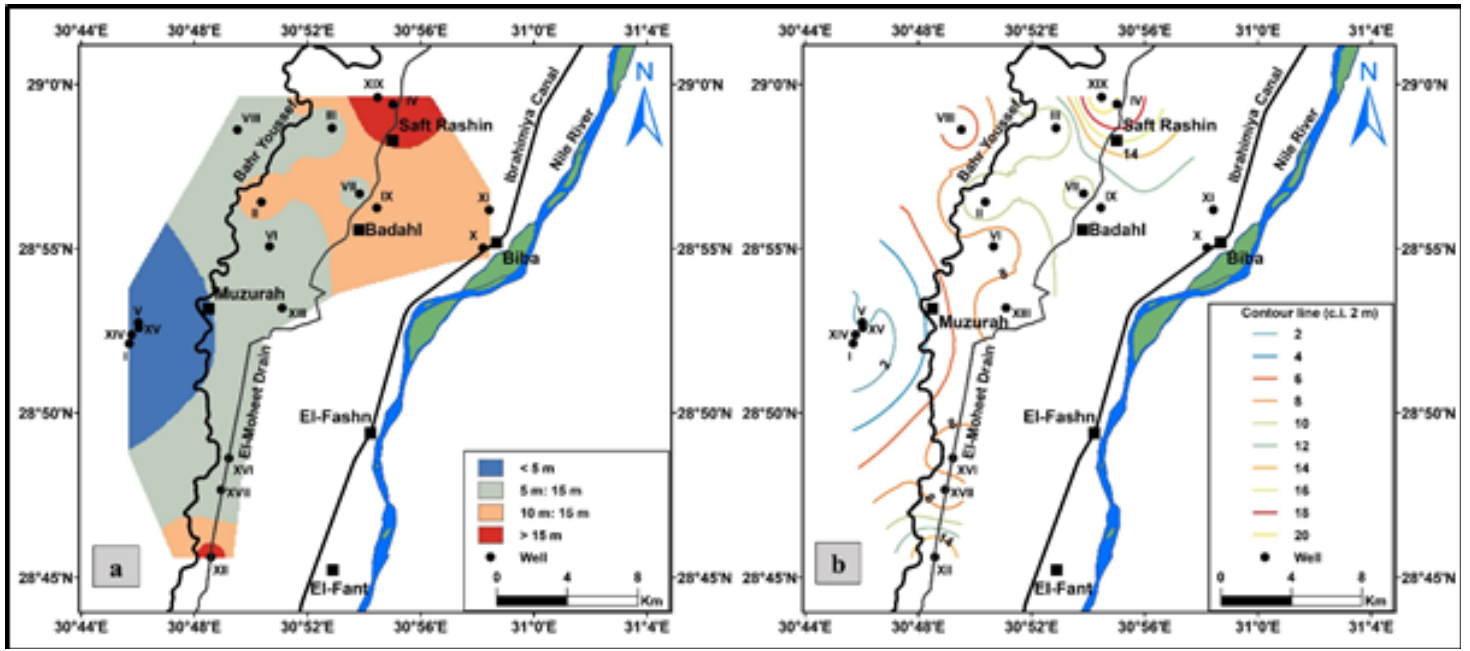

Fig. 4. Aquitard thickness map of the study area, data from REGWA (1996, 2003, 2014, 2017).

drawn to show the spatial and vertical distribution of the stratigraphic sequences, the depth to water table, and the hydrogeologic conditions in the study area, depending on the technical reports of thirteen wells (I to XIII) drilled by REGWA (REGWA, 1996, 2003, 2014, 2017) (Figs. 1 and 5 ). The Quaternary aquifer conditions vary from unconfined in the west to confined eastwards (El Sayed, 1993).

In the cross section $\mathrm{A}-\mathrm{F}^{\prime}-\mathrm{A}^{\prime}$, the Pleistocene aquifer is mainly composed of fluvial sediments which are represented by sand, sandy gravel, as well as gravelly sand with intercalations of clay lenses, clayey sand and sandy clay. This aquifer varies in thickness laterally, where the minimum thickness is recorded in the southwestern parts $(\sim$ $81 \mathrm{~m}$ ) and gradually increases toward the northeast direction $(\sim 105 \mathrm{~m})$. The aquitard thickness shows a gradual thinning from the northeast $(\sim 20 \mathrm{~m})$ to the southwest direction till it vanishes at the extreme southwest (Fig. 5a). Accordingly, the Pleistocene aquifer exhibit a confined condition in the northeast direction and unconfined conditions due southwest. The water table along this cross section $\left(A-F^{\prime}-A^{\prime}\right)$ varies from $31.85 \mathrm{~m}$ in well $\mathrm{I}$ and becomes shallower $(25.2 \mathrm{~m}$ and $26.25 \mathrm{~m}$ ) in wells III, and IV; respectively (Fig. 5a).

The cross section B-D-B' shows that the Pleistocene aquifer increases in thickness toward well VI, attaining a thickness of more than about $101 \mathrm{~m}$. Due the southwest direction, the Pleistocene aquifer thickness decreases to about $69 \mathrm{~m}$ in well V (Fig. 5b). The thickness of the aquitard along this direction is about $9 \mathrm{~m}$ in well VII and decreases due southwest to $\sim 4 \mathrm{~m}$ in well $\mathrm{V}$ (Fig. 5b). The water table is deeper in the southwest direction $(31.5 \mathrm{~m}$ in well V) and shallower in the northeast part $(26.23 \mathrm{~m}$ in well VII) (Fig. 5b). The groundwater flows from the southwest to the northeast direction.

The cross section along $\mathrm{C}-\mathrm{B}^{\prime}-\mathrm{C}^{\prime}$ reveals that the Pleistocene aquifer exhibits variable thickness with abundant lateral facies change (Fig. 5c). The aquifer thickness ranges from $93 \mathrm{~m}$ in well VII to $76 \mathrm{~m}$ in well VIII. The aquitard thickness increases from northwest to southeast and the aquifer is under confining conditions along this profile (Fig. 5c).

In the cross section D-C', the Pleistocene aquifer is composed almost of homogenous sands with few lenses of gravel, clay and clayey sands. The aquitard thickness diminishes from the east $(10 \mathrm{~m}$ in well $\mathrm{X})$ to the west direction $(6 \mathrm{~m}$ in well VI) (Fig. 5d).

The cross section $\mathrm{A}^{\prime}$-E runs in a northwest to southeast direction, showing the thickness variability of the Pleistocene aquifer (Fig. 5e). Due the northwest direction, it has a thickness of more than $105 \mathrm{~m}$ in well IV while in the southeast direction, it has a thickness of more than $90 \mathrm{~m}$ in well XI where the wells are not fully penetrating the aquifer. The Holocene clay aquitard thickness has a similar trend as the aquifer thickness; a maximum thickness of $20 \mathrm{~m}$ in well IV and a minimum thickness of $10 \mathrm{~m}$ in well XI (Fig. 5e).

In the cross section F-F', the Pleistocene aquifer is dominated by gravel lenses in the southern parts (well XII) while in the north it is mostly homogenous (Fig. 5f). The aquitard 
thickness diminishes toward the north direction from $16 \mathrm{~m}$ in well XII to $8 \mathrm{~m}$ in well III (Fig. 5f).

Accordingly, the aquifer thickness diminishes in both east and west directions and the aquitard thickness also decreases in the west direction until it vanished. The groundwater flows from west to east in addition to flowing with general slope; from south to north and northeast.

\section{The Aquifer Transmissivity}

The efficiency of aquifers is determined by transmissivity, storativity and hydraulic conductivity which are affected by several factors such as hydrogeological conditions, relation between total thickness and saturated thickness of the aquifer, its extension and lithofacies, recharge sources, discharge rate and well design. Aquitard also plays an important role in controlling aquifer conditions being unconfined, semi-confined and confined condition. The Middle Pleistocene aquifer is represented by 10 wells while the Early Pleistocene is represented by 4 wells (Fig. 6, Appendix 1). The transmissivity of the Early Pleistocene aquifer ranges from about 769 to 4796 $\mathrm{m}^{2} / \mathrm{d}$, while that of the Middle Pleistocene aquifer ranges from 656 to $28602 \mathrm{~m}^{2} / \mathrm{d}$. The Middle Pleistocene aquifer located in the south of Beni Suef is characterized by transmissivity ranges of about $10000 \mathrm{~m}^{2} / \mathrm{d}$ to $28000 \mathrm{~m}^{2} / \mathrm{d}$ while the Early Pleistocene aquifer has a transmissivity of about $4999.2 \mathrm{~m}^{2} / \mathrm{d}$ (El Sayed, 1993).
Accordingly, the Quaternary aquifer in the study area is characterized by high potentiality according to Gheorghe classification (Gheorghe, 1978). The transmissivity shows high values in the central parts of the study area and decreases in both east and west directions (Fig. 7). These variations could be attributed to the aquifer thickness, the saturation thickness, the clay content as well as the well design and development.

The storativity of the Quaternary aquifer in Beni Suef area was calculated by several workers, being about 12×10-2 (Attia et al., 1986), 1×10-3 (RIGW, 1986) and 4×10-4 (RIGW, 1992) while the calculated mean storativity of the Quaternary aquifer is 3.425 $\times 10-4$ (Abdel-Mageed, 1997).

The average hydraulic conductivity of the Middle Pleistocene (Prenile) aquifer of the study area is about $60 \mathrm{~m} / \mathrm{d}$ whearas that of the Early Pleistocene (Protonile) aquifer is about $50 \mathrm{~m} / \mathrm{d}$ (El Sayed, 1993).

Both the Middle Pleistocene and the Early Pleistocene aquifers in the west of Bahr Youssef canal (south Beni Suef) are hydraulically connected where the Bahr Youssef canal acts as a drain for both old cultivated and new reclaimed areas (El Sayed, 1993).

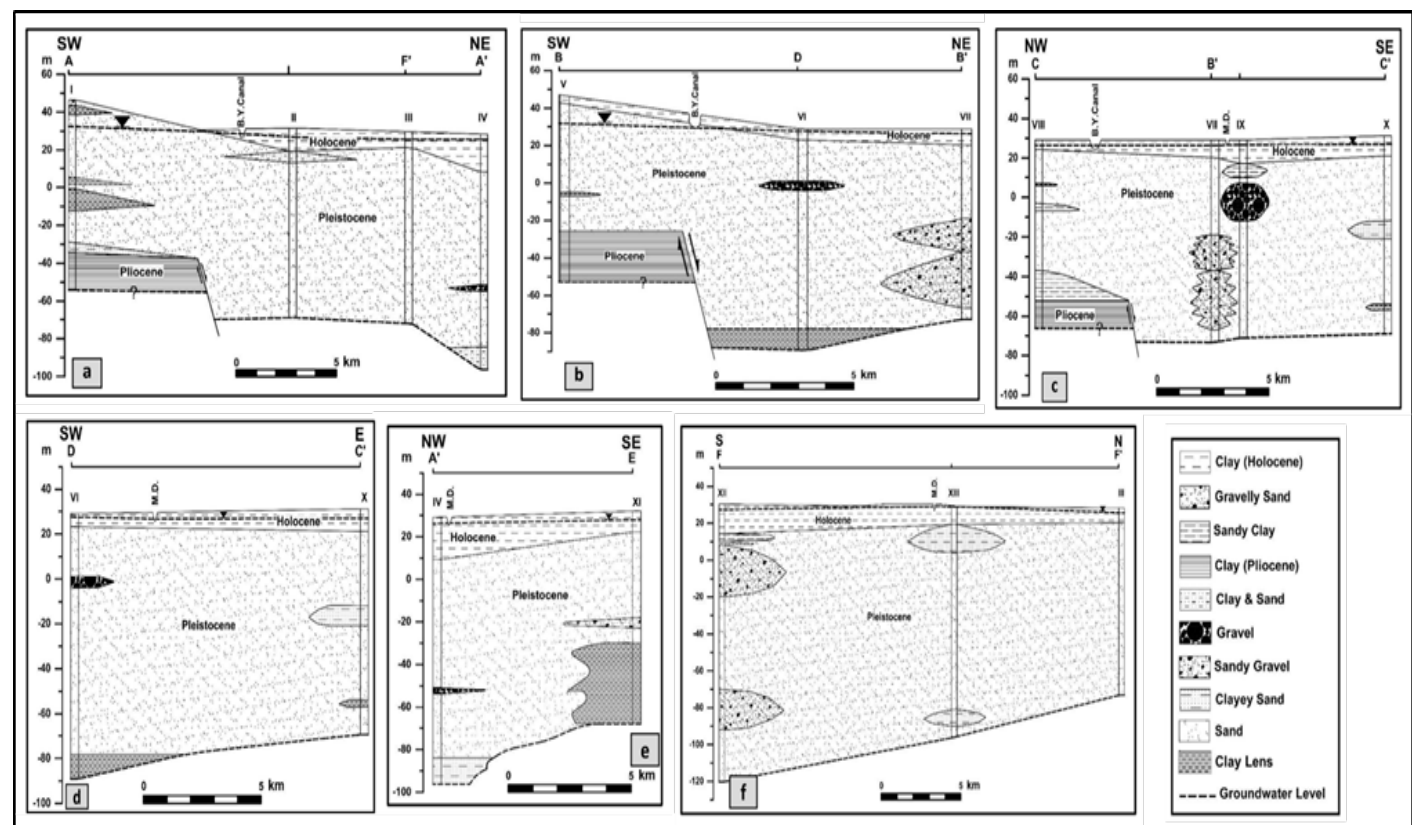

Fig. 5. Hydrogeological profiles (a) A-F'-A', (b) B-D-B', (c) C-B'-C', (d) D-C', (e) A'-E, and (f) F-F'. B.Y canal is the Bahr Youssef canal, M.D. is the Moheet drain. 

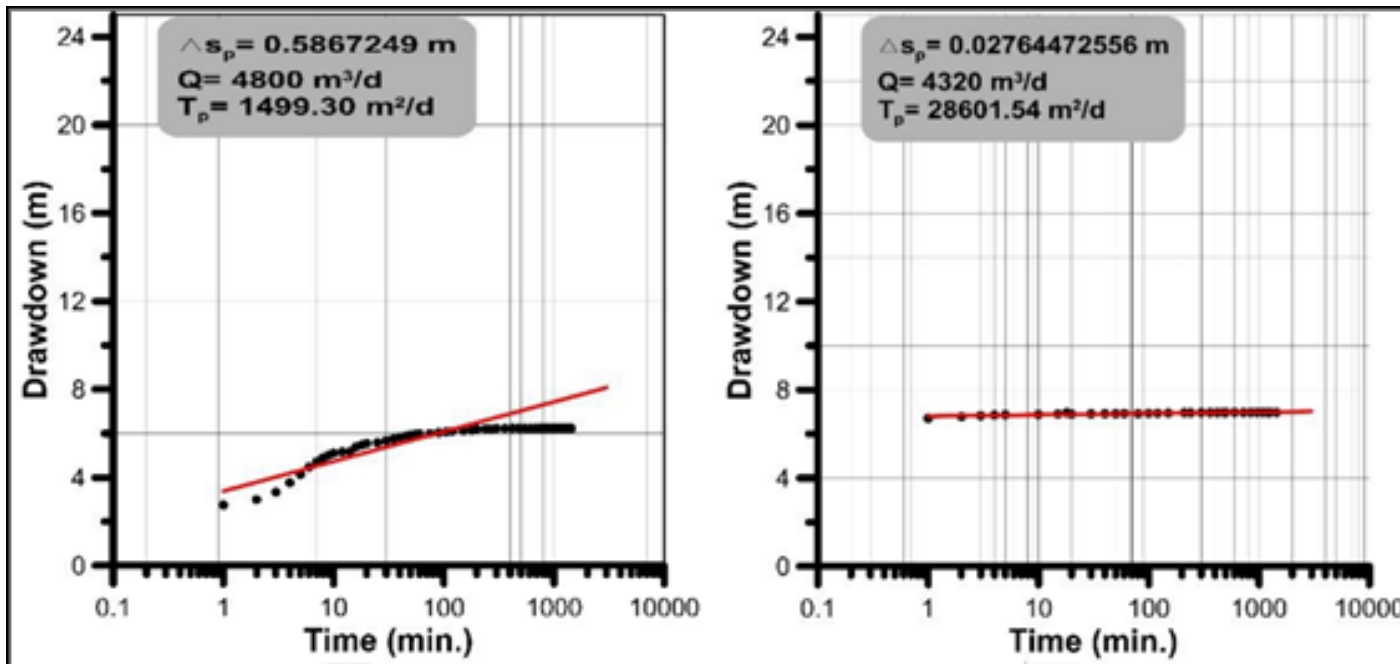

IV

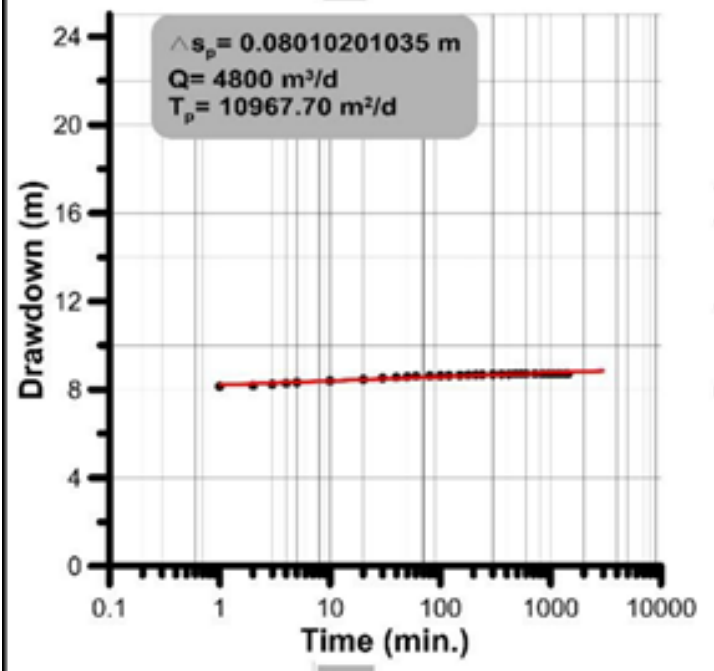

VII

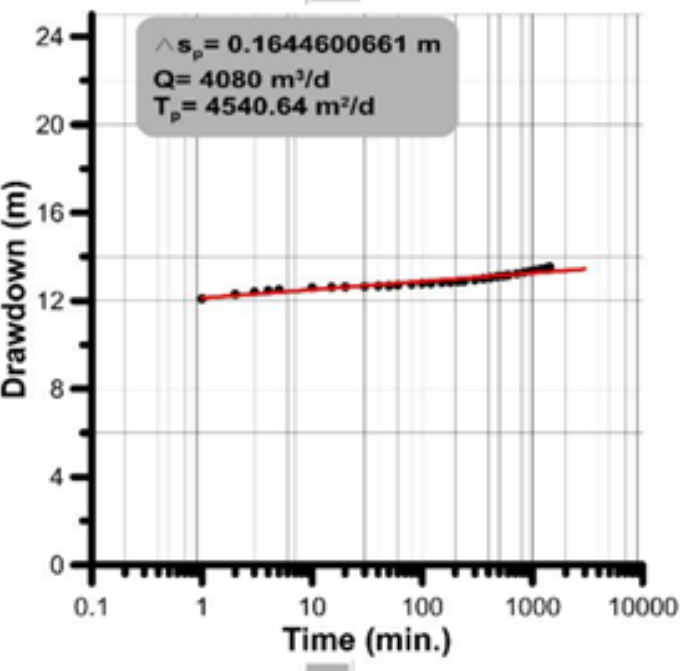

VIII

IX

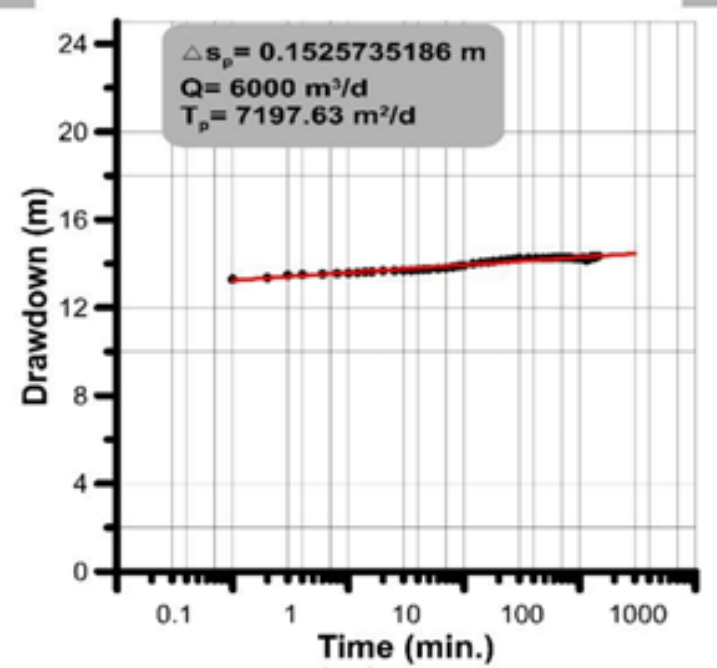

$\mathrm{x}$

Fig. 6. Pumping tests of selected wells a, b) Middle Pleistocene and c) Early Pleistocene aquifers (REGWA, 1996, 2003, 2014, 2017). 

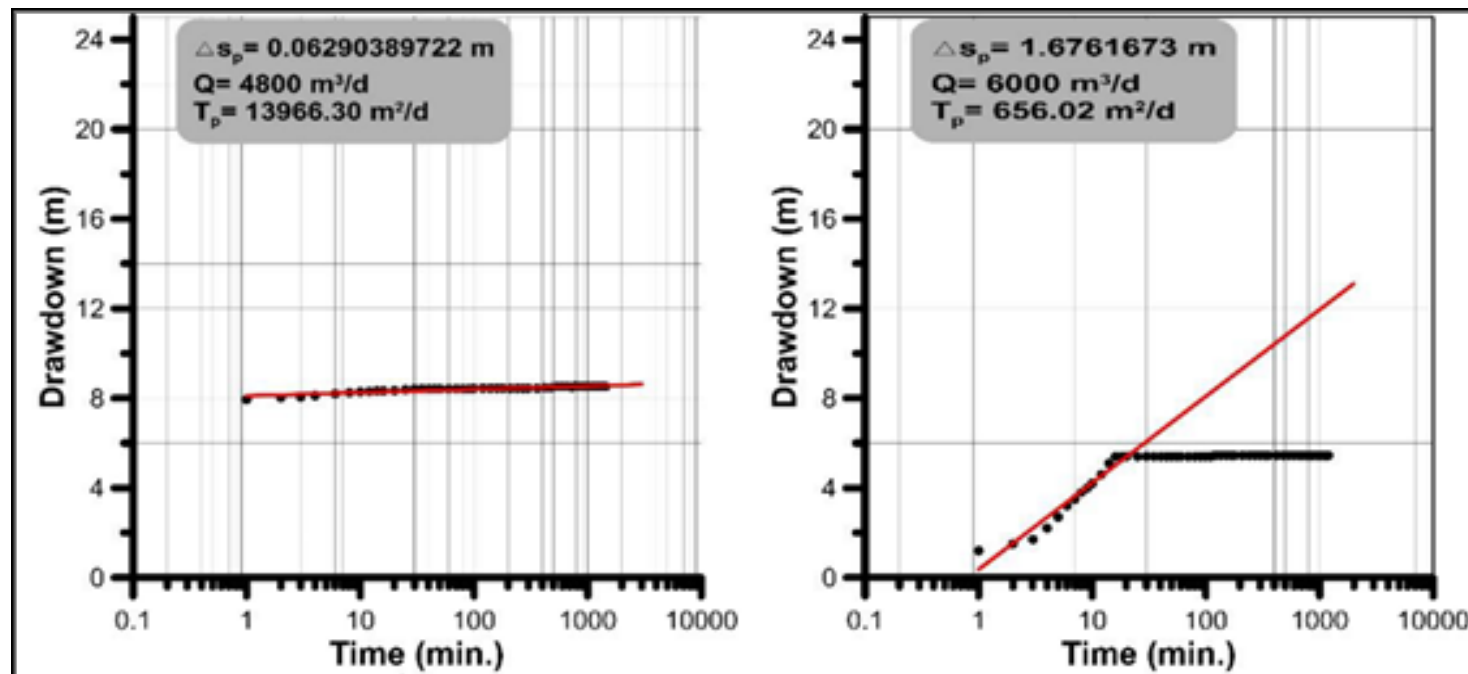

XI

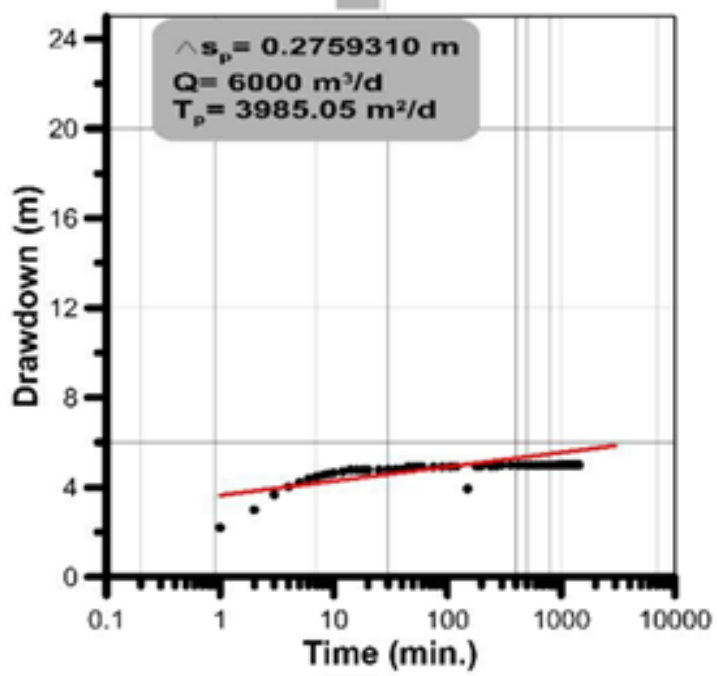

XII

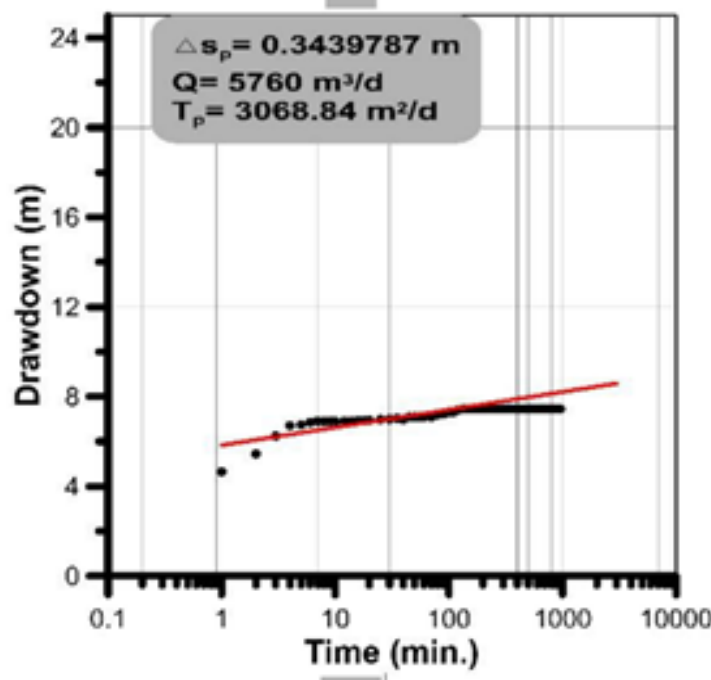

XIII

xvi

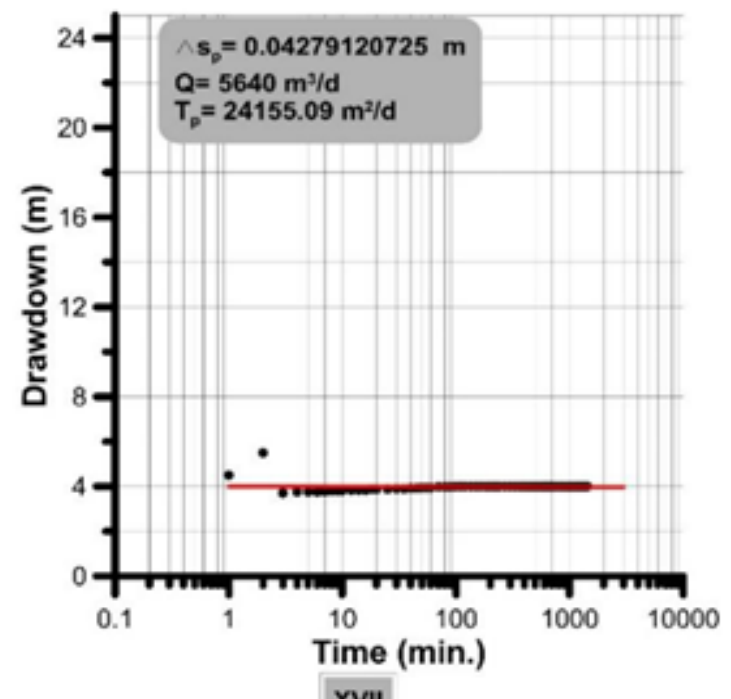

XVII

Continued Fig. 6

Egypt. J. Geo. Vol. 65 (2021) 

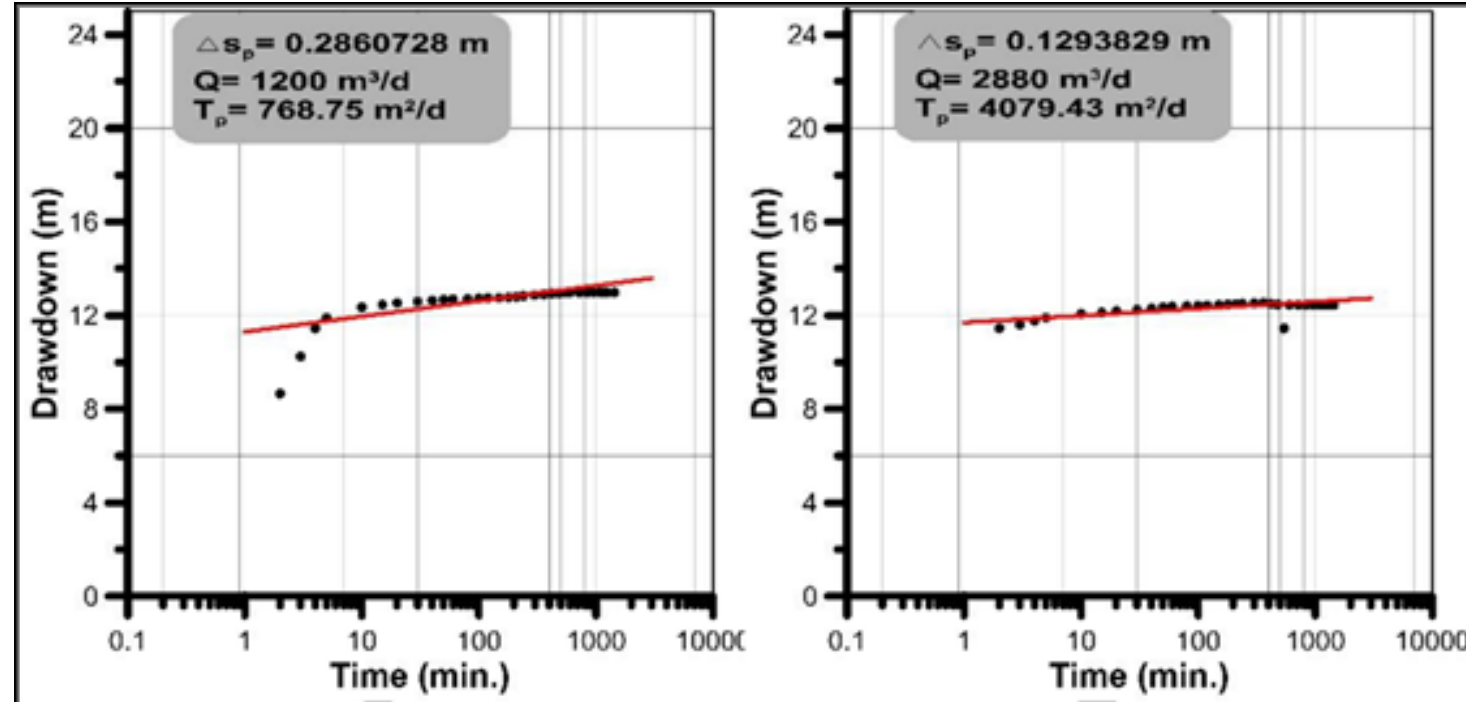

1
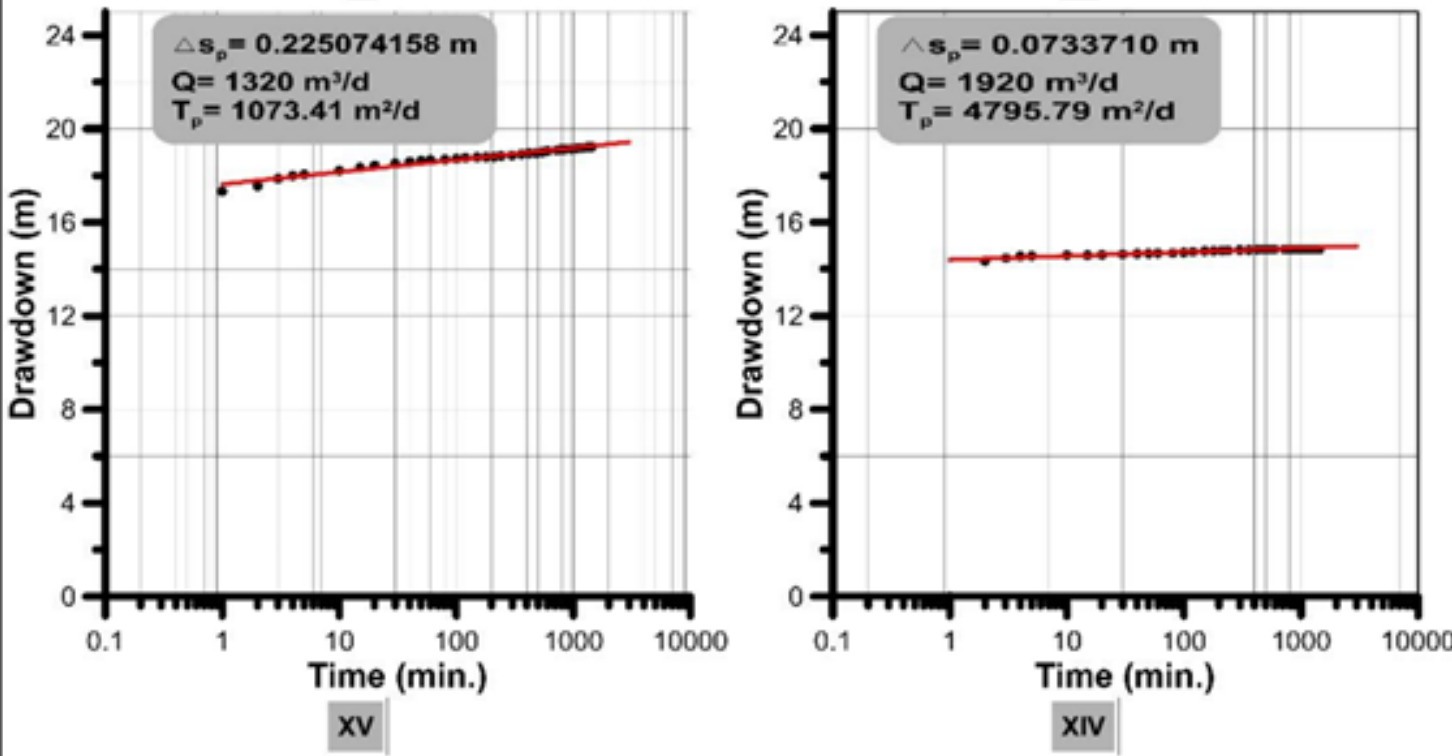

Continued Fig. 6

Historical Review of Water Table

Water table contour maps of the Quaternary aquifer for the years 1996 and 2014 were constructed on the basis of the technical reports of REGWA (1996, 2014) and compared to those of the years 1990 and 2003 obtained from technical reports of RIGW (1997) and REGWA (2003); Gad (2004) (Figs. 8 a, b, c, and d). The general groundwater flow is from west to east following the general slope of the Nile Valley. The water table contour maps that illustrate this trend are shown hereinafter.

In 1990, water table decreased from $40 \mathrm{~m}$ in the western and southwestern parts of the investigated area, to $28 \mathrm{~m}$ in the east and northeast parts (Fig. 8 a). In 1996, it changed from $32 \mathrm{~m}$ in the western high lands to $26 \mathrm{~m}$ in the north. In the northeast parts, local water table high $(28 \mathrm{~m})$ exist that may be attributed to seepage from the Ibrahimiya canal (Fig. 8 b). In 2003, the highest records of water table ranged between $42 \mathrm{~m}$ in the west and $40 \mathrm{~m}$ in the southwestern parts whereas the lowest records ranged between 25 to $29 \mathrm{~m}$ in the northeast and the east, respectively (Fig. 8 c). In 2014, water table decreased from $51 \mathrm{~m}$ in the west to about $26 \mathrm{~m}$ in the northeast direction (Fig. $8 \mathrm{~d}$ ).

Accordingly, the preceding water level maps show that groundwater flow did not change from 


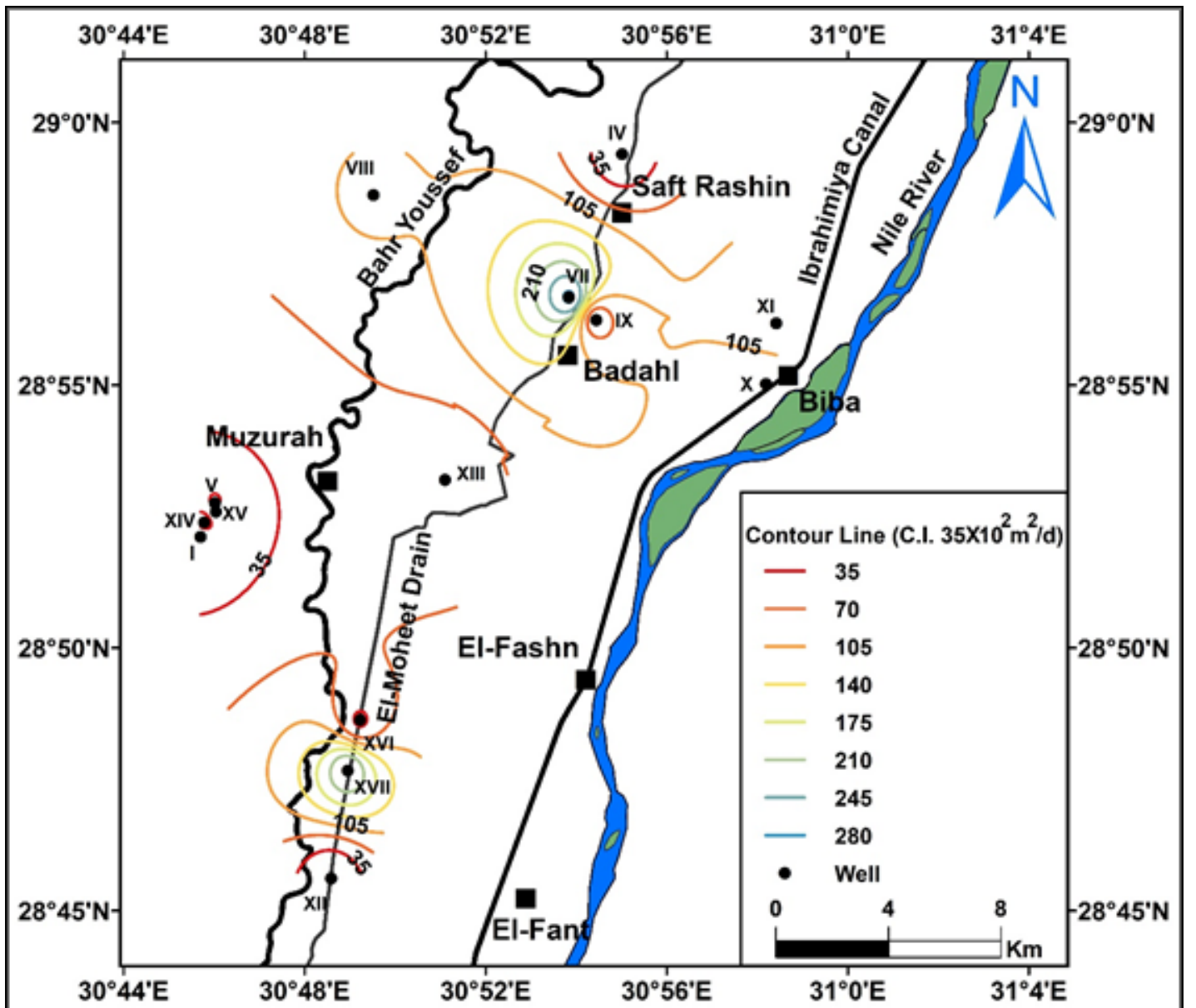

Fig. 7. Transmissivity contour map of the Quaternary aquifer in the study area, data from REGWA (1996, 2003, 2014, 2017). 


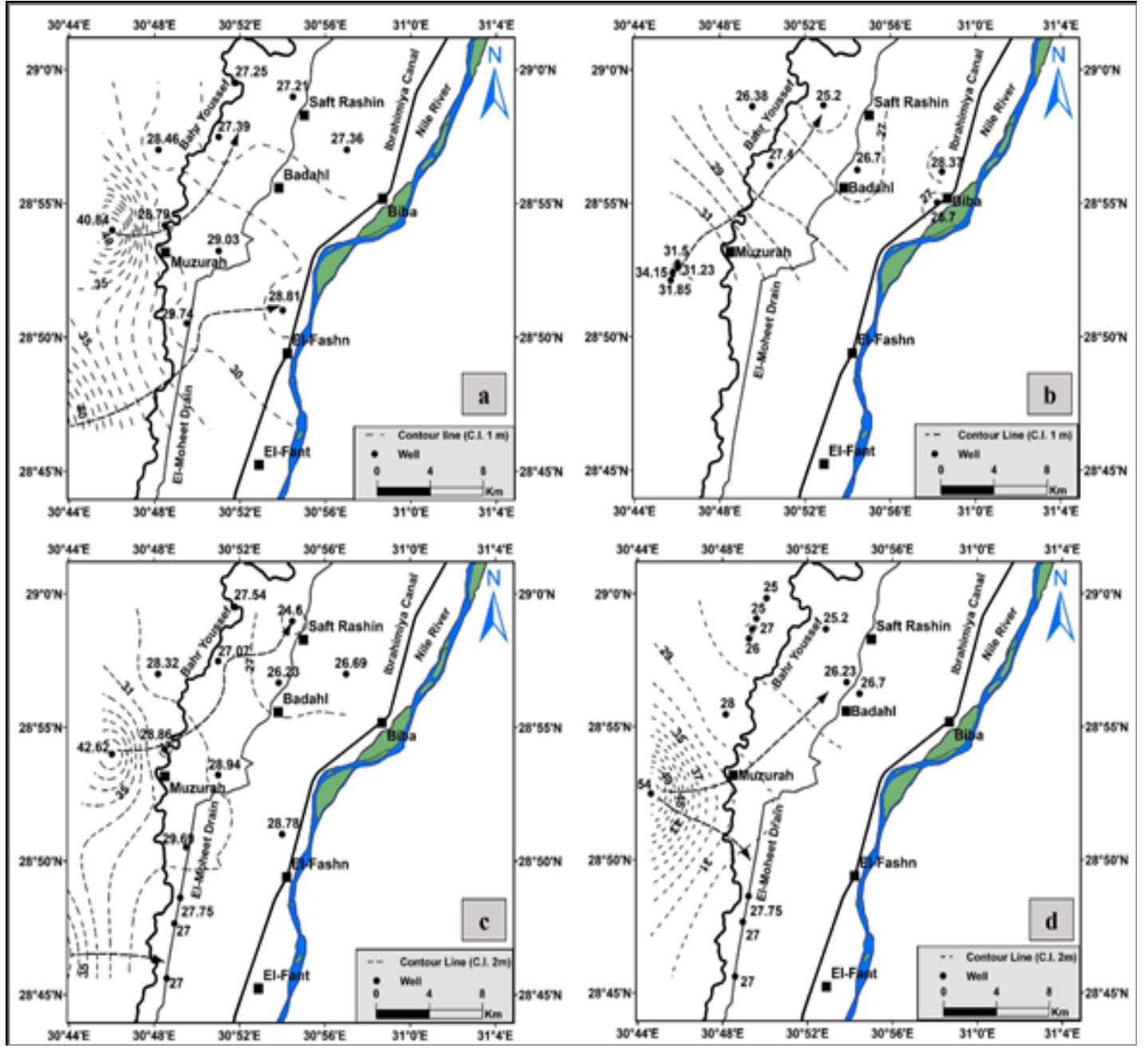

Fig. 8. Water table contour map of the Quaternary aquifer in a) 1990 (RIGW, 1997), b) 1996 (REGWA, 1996), c) 2003 (REGWA, 2003; Gad, 2004), and d) 2014 (REGWA, 2014).

1990 to 2014, though there is a slight change in groundwater levels where a slight rise is apparent in the west of the study area which may be related to flood irrigation technique.

\section{Waterlogging Phenomena}

The study area is characterized by waterlogging problem, which has a threatening effect on the soil due to the arisen salinity (Fig. 9). This problem is caused by the topographic nature of the study area due to the high ground elevations in the west, the poor drainage of the soil and the use of flood irrigation systems ( $\mathrm{Gad}, 2004)$, in addition to the increased aquitard (soil) thickness as well as the shallow water table.

The excessive usage of water in irrigation leads to waterlogging and finally soil salinization (Al-Murad, et al., 2017). Other factors such as soil thickness (Houk, et al., 2005, 2006), soil type, geology and geomorphology play important role in the occurrence of waterlogging and salinization problems in agricultural area (Hatton, et al., 2002; McFarlane and Williamson, 2002; Holden, et al., 2006). Additionally, high rainfall, poor drainage, hard pan and seepage from canals are reasons for waterlogging occurrence (Pandey, et al., 2015).

The study area is classified into three zones based on the classification of the Indian Ministry of Water Resources for waterlogging areas (MOWR, 1991) (Fig. 10). The southern part of the study area is characterized by waterlogged area where the depth to water is $1.25 \mathrm{~m}$ from the land surface, while potential areas prevail in the centre of the north and south parts. The east and west of the study area display safe areas where the depth to water is more than $3 \mathrm{~m}$ from land surface. 

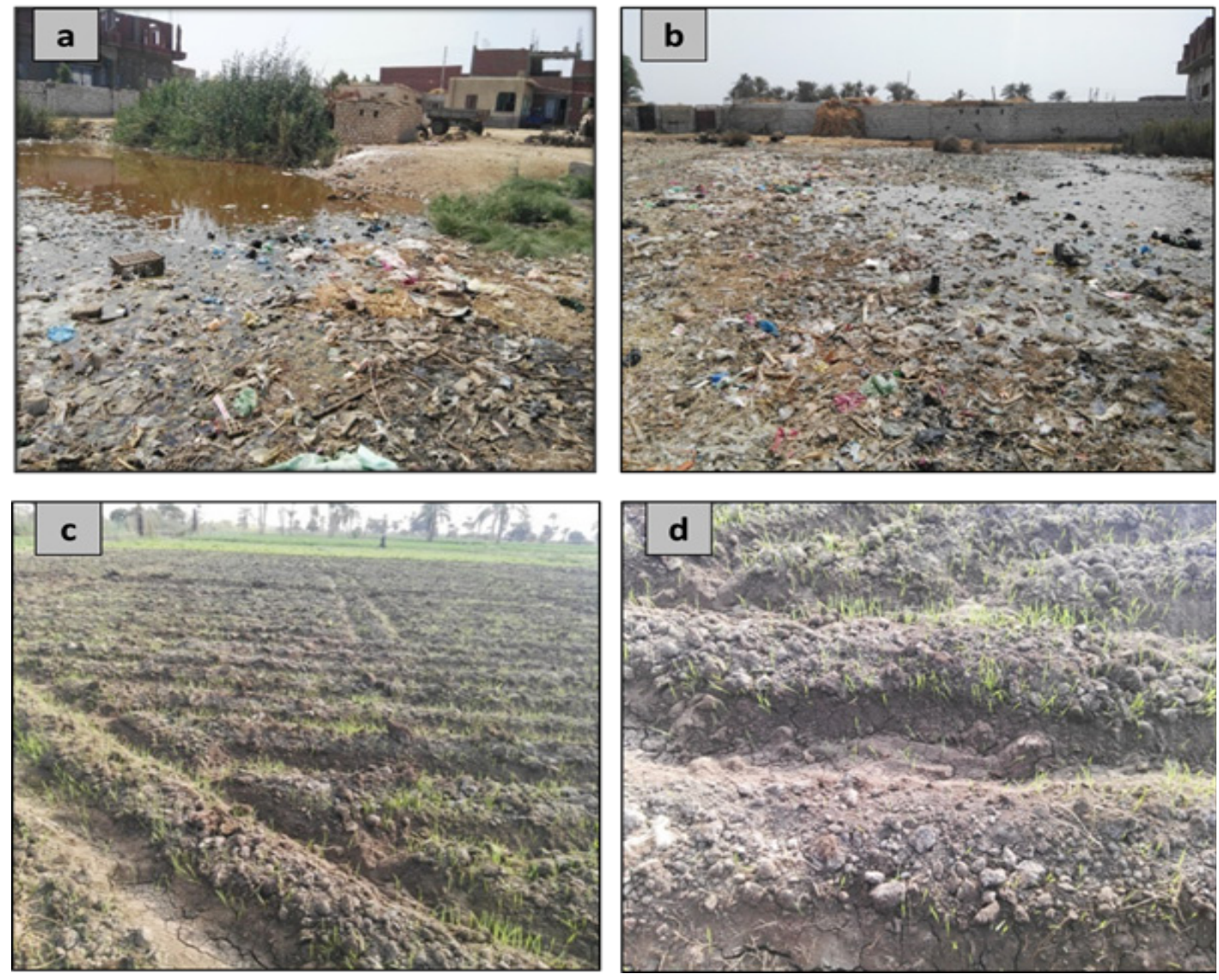

Fig. 9. The waterlogging problem in the study area (a and b), and the waterlogging effect on the soil in the study area (c and d).

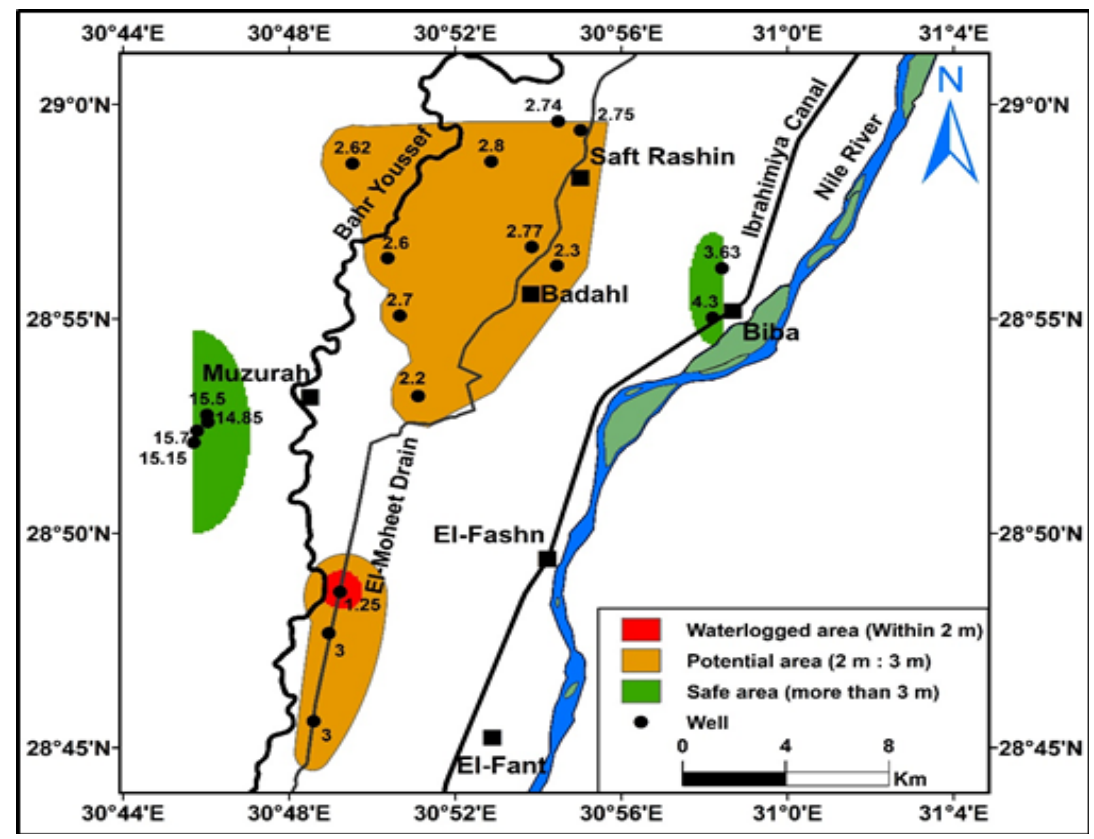

Fig. 10. Waterlogging area map of the study area based on the depth to water values.

Egypt. J. Geo. Vol. 65 (2021) 


\section{Conclusions}

Groundwater represents a significant part of the total water resources used for drinking and irrigation purposes, especially in arid and semiarid areas) Tsujimura et al ;2007, ,Keesari et al . (2014, ,The increase of groundwater usage is remarked due to drought, growth of the worldwide economy as well as population) Llamas and Martínez-Santos.(2005,

The study area is represented by El Fashn District ,Beni Suef Governorate ,Egypt ,that lies on the west flood plain of the River Nile valley where the main developmental activities is agriculture .The essential water resources used for irrigation and domestic purposes are the Nile River ,the Ibrahimiya canal ,Bahr Youssef canal, irrigation canals and drains in addition to groundwater. Groundwater is only used in areas distant from the surface water or in seasons of increased demand) as in summer .(Moreover, waterlogging is dominant in some parts of the study area ,resulting in soil amendment and may be land abandonment.
Therefore ,the objective of this study is the investigation of the hydrogeological properties of the Quaternary aquifer in Beni Suef area based on the data obtained from the technical reports of REGWA for the years $2014,2003,1996$ and .2017In addition ,the waterlogging phenomena is considered to allocate the areas that adversely affected by soil salinization.

The study shows that the investigated area is characterized by two main aquifers :The Middle Pleistocene and the Early Pleistocene aquifers. The Holocene sediments act as aquitard of the Middle Pleistocene whereas the Early Pleistocene is lacking the Holocene aquitard .Accordingly, the study area is classified on the basis of aquitard thickness into four zones, where a maximum thickness exists in southern and northeast parts and minimum thickness dominate the western parts of the study area .This variation leads to varying aquifer conditions from unconfined in the west to semi-confined and confined in central and eastern parts .Similarly, the Middle Pleistocene aquifer has a maximum thickness of $200 \mathrm{~m}$ in the middle parts of the Nile valley near

Appendix 1: Hydrogeological characteristics of the Quaternary aquifer

\begin{tabular}{|c|c|c|c|c|c|c|}
\hline $\mathrm{X}\left({ }^{\circ} \mathrm{E}\right)$ & $\mathrm{Y}\left({ }^{\circ} \mathrm{N}\right)$ & Hole ID & Aquifer & Condition & $\begin{array}{c}\text { Aquitard } \\
\text { Thickness (m) }\end{array}$ & Transmissivity $\left(\mathrm{m}^{2} / \mathrm{d}\right)$ \\
\hline 30.761711 & 28.868553 & I & \multirow{4}{*}{ 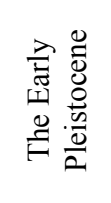 } & \multirow{4}{*}{ 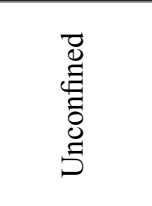 } & 0 & 768.75 \\
\hline 30.767019 & 28.879317 & $\mathrm{~V}$ & & & 4 & 4079.43 \\
\hline 30.767361 & 28.876508 & $\mathrm{XV}$ & & & 0 & 1073.41 \\
\hline 30.763072 & 28.873081 & XIV & & & 0 & 4795.79 \\
\hline 30.881081 & 28.977803 & III & \multirow{15}{*}{ 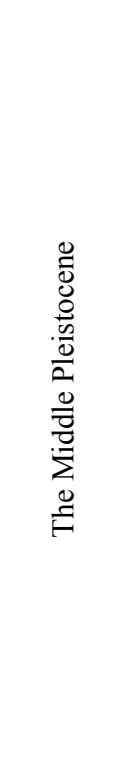 } & \multirow{15}{*}{ 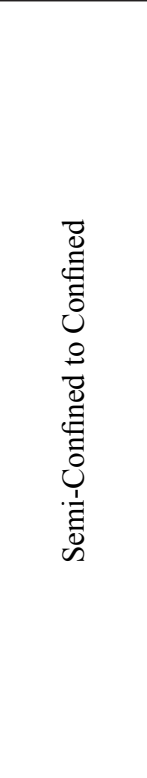 } & 8 & $\ldots \ldots$ \\
\hline 30.917000 & 28.989944 & IV & & & 20 & 1499.30 \\
\hline 30.844361 & 28.917806 & VI & & & 6 & $\ldots \ldots$ \\
\hline 30.897325 & 28.944528 & VII & & & 9 & 28601.54 \\
\hline 30.825411 & 28.977008 & VIII & & & 5 & 10967.7 \\
\hline 30.907469 & 28.937344 & IX & & & 12 & 4540.64 \\
\hline 30.969972 & 28.917056 & $\mathrm{X}$ & & & 10 & 7197.63 \\
\hline 30.973750 & 28.936306 & XI & & & 10 & 13966.3 \\
\hline 30.809778 & 28.760278 & XII & & & 16 & 1060 \\
\hline 30.851694 & 28.886611 & XIII & & & 10 & 3985.05 \\
\hline 30.820372 & 28.810444 & XVI & & & 9 & 3068.84 \\
\hline 30.815833 & 28.794417 & XVII & & & 7 & 24155.09 \\
\hline 30.842917 & 28.803639 & XVIII & & & $\ldots \ldots$ & $\ldots \ldots$ \\
\hline 30.839506 & 28.940283 & II & & & 12 & $\ldots \ldots$ \\
\hline 30.907972 & 28.993472 & XIX & & & 22 & $\ldots \ldots$ \\
\hline
\end{tabular}

Egypt. J. Geo. Vol. 65 (2021) 
Beni-Suef and diminishes in both the eastern and western directions, whereas the Early Pleistocene aquifer thickness ranges from $81 \mathrm{~m}$ to $85 \mathrm{~m}$ with a saturated thickness of 64 to $82 \mathrm{~m}$ in the study area.

The transmissivity of the aquifer is obtained using Cooper-Jacob method for the investigated wells. For the Early Pleistocene aquifer, it ranges from about 769 to $4796 \mathrm{~m}^{2} / \mathrm{d}$, while that of the Middle Pleistocene aquifer ranges from 656 to $28602 \mathrm{~m}^{2} / \mathrm{d}$. Accordingly, the Quaternary aquifer in the study area is characterized by high potentiality according to Gheorghe classification (Gheorghe, 1978).

Comparison between the water level maps indicate that there is no change in the groundwater flow direction (from west to northeast direction with the general slope). However, there is a slight change in groundwater level in the west of the study area where rising groundwater level, which may be related to flood irrigation technique.

The waterlogging phenomena is investigated in the study area where bad effects on soil are recorded. The investigated area was classified into three areas based on the Indian Ministry of Water Resources classification for waterlogging, where waterlogged areas characterize the southern parts, potential areas exist in the centre of the northern and southern parts of the study area. Safe areas dominate the east and the west of the study area. Accordingly, it is better to use advanced irrigation techniques rather than flood (e.g., drip or sprinkler methods).

\section{Acknowledgments}

This paper is based upon MSc thesis supported by Geology Department, Faculty of Science, Cairo University. The authors are grateful to Eng. Emad Youssef Sanad for his cooperation and providing technical data used in this work.

\section{References}

Abdel-Mageed, G. (1997) "Hydrogeological and hydrogeochemical studies of the Nile Valley area, Beni Suef governorate, Egypt.” M. Sc. Thesis, Cairo Univ., Giza

Al-Murad, M., Uddin, S., Rashid, T., Al-Qallaf, H. and Bushehri, A. (2017) Waterlogging in Arid Agriculture Areas Due to Improper Groundwater Management-An Example from Kuwait. Sustainability 9 (1) :2131.

Attia, F.A., Allam, M.N., Amer, A.W. (1986) A hydrologic budget analysis for the Nile Valley in
Egypt. J.GRoundw. 24 (4) :453-459.

Attia, M.I. (1954) Deposits in the Nile Valley and the Delta. Egypte. Geol. Surv., Government Press

Butzer, K. and Hansen, C. (1968) Desert and Rivers in Nubia: Madison, Wisconsin. University of Wisconsin Press. p 562

Continental Oil C, Squyres, C.H., Klitzsch, E., Handley, R., List, F.K., Pöhlmann, G. and Hayah al-Misriyah al-`Ammah 1-B (1987) Geological map of Egypt 1:500,000. NH 36 SW, NH 36 SW. Conoco Coral, Cairo, Egypt

Cooper Jr, H. and Jacob, C.E. (1946) A generalized graphical method for evaluating formation constants and summarizing well field history. Eos, Trans. $A G U ., 27$ (4) :526-534.

Egyptian Environmental Affairs Agency (2003) Environmental characterization of Beni Suef Governorate. http://www.eeaa.gov.eg/arabic/info/ report_gov_profiles.asp

El Abd, E. (2015) Hydrogeological study of the groundwater aquifers in the reclamation area of the desert fringes east Nile between Biba-El Fashn, eastern desert, Egypt. EJPAS 53:13-25.

El Sayed, E. (1993) "Hydrogeological studies of the Nile Valley in the northern portion of upper Egypt." Ph. D Thesis, Faculty of Science, El-Minia Univ., Egypt, 115p

Fernández Cirelli, A., Arumí, J.L., Rivera, D., Boochs, P.W. (2009) Environmental Effects of Irrigation in Arid and Semi-Arid Regions .Chilean J. Agric. Res. 69:27-40.

Gad, M. (2004) A Trial for Mitigation of Water Logging Problem in New Reclaimed Areas in the Desert Fringes of Beni-suef and El-Minya Governorates, Egypt. MEJ. Mansoura Engineering Journal 29 (2):33-52.

Gheorghe, A. (1978) Processing and synthesis of hydrological data. Abacus Press Junebridge Wells, Kent 290:122-136.

Hassan, M., Issawi, B. and Zaghloul, E. (1978) Geology of the area east of Beni Suef, eastern Desert, Egypt. Ann. Geol. Surv. Egypt 8:129-162.

Hatton, T., Bartle, G., Silberstein, R., Salama, R., Hodgson, G., Ward, P., Lambert, P. and Williamson, D. (2002) Predicting and controlling water logging and groundwater flow in sloping duplex soils in western Australia. Agric. Water Manag. 53:57-81. 
Holden, J., West, L.J., Howard, A.J., Maxfield, E., Panter, I. and Oxley, J. (2006) Hydrological controls of in situ preservation of waterlogged archaeological deposits. Earth Sci. Rev. 78:59-83.

Houk, E., Frasier, M. and Schuck, E. (2005) Irrigation technology decisions in the presence of waterlogging and soil salinity. Glob. Bus. Econ. Rev. 7:343-352.

Houk, E., Frasier, M. and Schuck, E. (2006) The agricultural impacts of irrigation induced waterlogging and soil salinity in the Arkansas Basin. Agric. Water Manag. 85:175-183.

Keesari, T., Kulkarni, U.P., Deodhar, A., Ramanjaneyulu, P.S., Sanjukta, A.K. and Saravana Kumar U. (2014) Geochemical characterization of groundwater from an arid region in India. Environ. Earth Sci. 71:4869-4888. doi:10.1007/s12665-0132878-x.

Köppen, W. (1918) Klassifikation der Klima nach Temperatur, Niederschlag und Jahreslauf. PGM 64, 193-203.

Llamas, M.R. and Martínez-Santos, P. (2005) Intensive groundwater use: silent revolution and potential source of social conflicts.

McFarlane, D.J. and Williamson, D.R. (2002) An overview of water logging and salinity in southwestern Australia as related to the 'Ucarro'experimental catchment. Agric. Water Manag. 53:5-29.

MOWR (1991) Report of the Working Group on Problem Identification in Irrigated Areas with suggested Remedial Measures. Ministry of Water Resources, Govt. of India, New Delhi.

Pandey, D., Singh, S. and Singh, G. (2015) Underprivileged agriculture: retrospection and future prospects. Compendium of Lectures on Management of Underprivileged Agriculture Pant University of Agriculture and Technology, Pantnagar 311p.

Peel, M.C., Finlayson, B.L. and McMahon, T.A. (2007) Updated world map of the Köppen-Geiger climate classification. Hydrol. Earth Syst. Sci. 11:16331644. doi:10.5194/hess-11-1633-2007

REGWA (1996) Technical Reports for drilled wells. REGWA

REGWA (2003) Technical Reports for drilled wells. REGWA.
REGWA (2014) Technical Reports for drilled wells. REGWA

REGWA (2017) Technical Reports for drilled wells. REGWA

RIGW (1986) Development and mangement of groundwater resources in the Nile Valley and Delta. RIGW. IWACO

RIGW (1992) Hydrogeological map of Egypt. Research Institute for Groundwater

RIGW (1997) Information Book, Ver.1: Inter. Report.

Said, R. (1975) Some observations on the geomorphological evolution of the south-western desert of Egypt and its relation to the origin of ground water. Ann. Geol. Surv. Egypt 5:61-70.

Said, R. (1981) "The geological evolution of the River Nile". Springer Verlag. Heidelberg, New York, $151 \mathrm{p}$.

Said, R. (1990) "the Geology of Egypt" Brookfield, Balkema, Rotterdam, New York, 487-507.

Sarvade, S., Gautam, D.S., Kathal, D. and Tiwari, P. (2017) Waterlogged wasteland treatment through agro-forestry: A review. J. Appl. Nat. Sci. 9 (1) :4450. doi:10.31018/jans.v9i1.1147.

The National Centers for Environmental Prediction's Climate Forecast System Reanalysis CFSR (20112013) Global Weather Data for SWAT C.F.S.R. https:/globalweather.tamu.edu/ Accessed 19 Augest 2019.

Tsujimura, M., Abe, Y., Tanaka, T., Shimada, J., Higuchi, S., Yamanaka, T., Davaa, G. and Oyunbaatar, D. (2007) Stable isotopic and geochemical characteristics of groundwater in Kherlen River basin, a semi-arid region in eastern Mongolia. $J$. Hydrol. 333:47-57. doi:https://doi.org/10.1016/j. jhydrol.2006.07.026. 


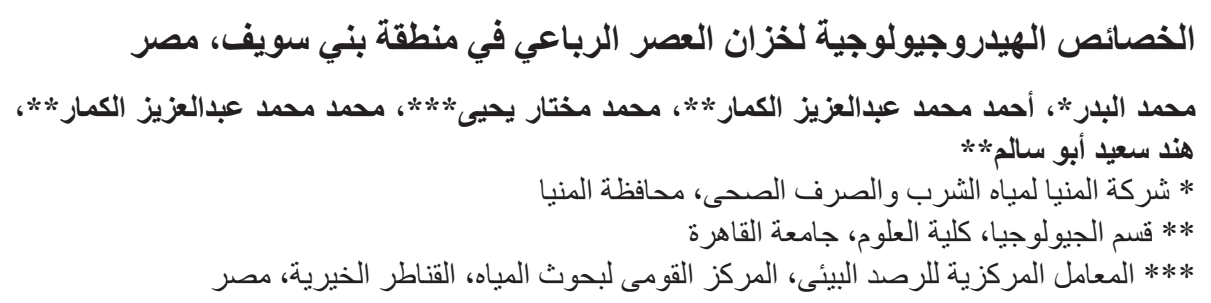

يؤدي استغلال المياه الجوفية في المناطق الحارة وشبه الحارة إلى العديد من المخاطر مثل انخفاض منسوب ونداب

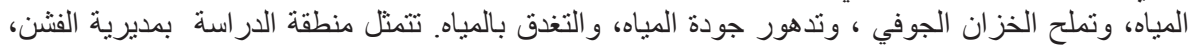

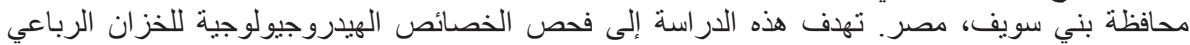

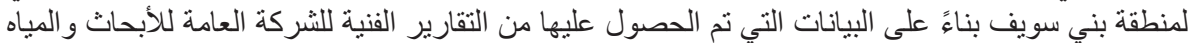

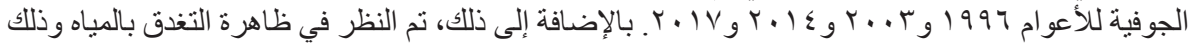
لتحديد المناطق التي تأثرت سلبا من تملح التربة.

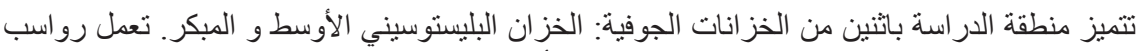

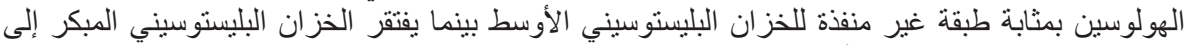

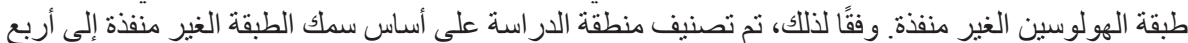

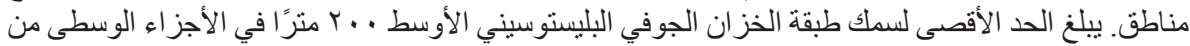

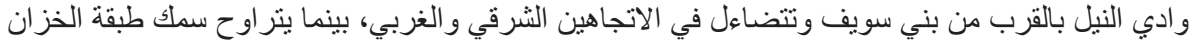

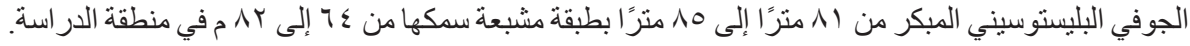

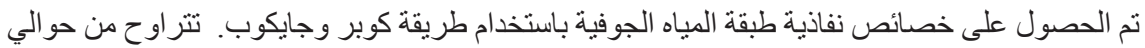
الجو V79 إلى VY

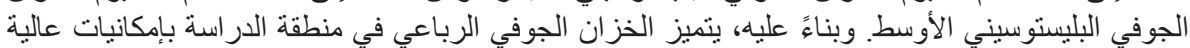

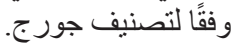

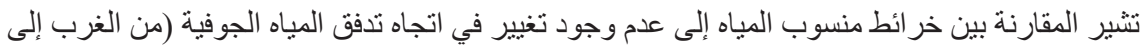

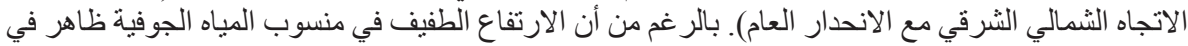

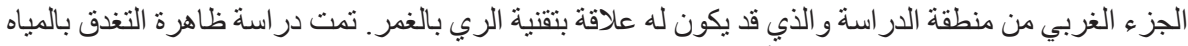

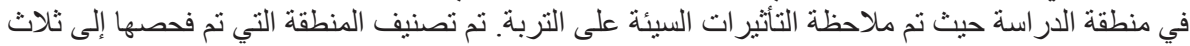

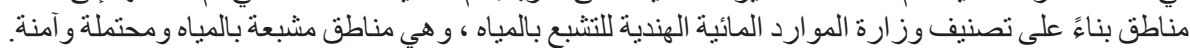

